\title{
Does Profitability moderate the relationship of Interest Rate, Ratio Tangible Assets, Firm Size on Capital Structure
}

\author{
Irawan $^{1}$, Muhammad Dharma Tuah Putra Nasution ${ }^{2 *}$, Yossie Rossanty ${ }^{3}$ \\ \{dharma_nasution@dosen.pancabudi.ac.id*\} \\ ${ }^{1,2,3}$ Department of Management, Faculty of Social Science, Universitas Pembangunan Panca Budi, \\ Medan, Indonesia
}

\begin{abstract}
The purpose of this study is to examine the effect of interest rate, asset structure, firm size, and profitability on the capital structure simultaneously and partially in firms of miscellaneous industry sector listed on the Indonesia Stock Exchange (IDX) and to test the effect of profitability moderate factors affecting capital structure. The population of this study is thirty-eight companies based on in firms of miscellaneous industry sector listed on the Indonesia Stock Exchange (IDX) for the 2010-2014 period. Determination of sample research using purposive sampling method with the number of 23 companies related to criteria. The data were processed using multiple linear regression test method, and moderating test using the absolute difference. The results of the study prove that BI rate, Ratio Tangible Assets, Firms Size, and Return on Assets have the significant effect on the capital structure at firms of miscellaneous industry sector listed on the Indonesia Stock Exchange (IDX) for the 2010-2014 period simultaneously. Partial test results indicate that only Ratio Tangible Assets and Return on Assets variables significantly influence the capital structure for the period 2010-2014. The moderating test demonstrates that profitability does not prove to be a moderating variable which means the variable is unable to strengthen or weaken and moderate BI rate, Ratio Tangible Assets, and Firms Size relationships with capital structure in in firms of miscellaneous industry sector listed on the Indonesia Stock Exchange (IDX) for the 2010-2014 period.
\end{abstract}

Keywords: $\quad$ Interest Rate, Ratio Tangible Assets, Firm Size, Profitability, Capital Structure

\section{Introduction}

Capital structure is a combination of funding derived from equity and debt. If the proposed funding policy is a low leverage policy, usually the companies have to pay small dividends. This case means that companies tend to refrain from issuing the new shares require the securities issuance cost and marketing cost. The company determines the capital structure in evaluating the investment type, and funding required of the retained earnings or derived from the debt. The literature showed the two theories proposed to use the capital structure which is Trade-off Theory and Pecking Order Theory. Based on Trade-off Theory by (Myers, 1984) explain that the companies based themselves on the decision an optimal capital structure. The optimal capital structure is formed with a balanced profit in debt used on the cost of bankruptcy. The companies generated profits by increasing the debt amount is higher than the debt risk, then the addition of debt can be permitted. Meanwhile, the other authors explain that the company capital structure is influenced by many factors, the interest rate, the stability of earnings, the structure of assets, the risk level of the assets, the amount of capital required, the state of the capital market, the nature of management, the size of a company (Bambang, 2001). 
This study attempts to investigate several factors affecting the capital structure. The variables studied were interest rate variable, asset structure, firm size and added profitability as moderating variable. The use of independent variables is due to the proven results of different studies that need further testing to strengthen the previous research results. The reason to use profitability as a moderating variable is profitability as an element of the company's success in generating profits. High and low profitability tend to strengthen or weaken the relationship of these profitability factors. Objects in this study are firms of miscellaneous industry sector listed on the Indonesia Stock Exchange (IDX) for the 20102014 period. The reason for using this industrial company is that the companies have relatively large production activities, and indeed requires large capital for operational activities. Also, the industry produces the variety of products with fast production rate, thus causing relatively sensitive capital structure in influencing factors.

\section{Literature Review}

\subsection{Capital Structure (DER)}

The study by (Wijaya, 2005) explain that capital structure is the right side of the balance sheet, and it is a combination of debt and capital. The research is concerned with the composition of these two things, commonly known as DER (Debt to Equity Ratio) or Leverage [debt $/($ debt + equity)]. The various fundamental funding factors are considered to influence this composition and subsequently is tested. Debt is usually associated with financial distress, and expected return.

\subsection{Trade-off Theory}

Trade-off theory by (Myers, 1984) reveals that the company will take on debt up to certain debt levels where tax shields from additional debt are equal to financial distress. Financial distress is bankruptcy costs or reorganization, and increased agency costs that result from declining credibility of corporate.

\subsection{Pecking Order Theory}

Pecking Order Theory emphasizes the companies capital structure of internal funds derived from retained earnings. The company should reduce debt rather than increase debt in their capital structure. The pecking order theory explains that management systematically prioritizes investment fund by using internal funds sources (retained earnings) rather than external funds, and prioritizing debt rather than equity if external funds are required. In pecking order perspective, firms should use as many internal funds as possible to fund the new projects. If internal funds are insufficient, then the safest debt or securities are prioritized over other external sources of funds (Sartono, 2001).

\subsection{Factors Affecting Capital Structure}

According to (Sartono, 2001) there are several factors to consider in determining the capital structure policy:

1) Suitability is an adjustment between the way the fulfillment of funds with the period of their needs. If the company needs a short-term source of funds, when purchased with debt, bonds or by issuing own capital is less appropriate. On the contrary, the way of fulfilling the funds is adjusted to the period of needs, if the short-term funds' needs, it 
should be fulfilled from short-term fund sources and if long-term fund needs, it should be fulfilled from long-term fund sources.

2) Control, Company is in the handle of shareholders. Company management has to execute the shareholder's decision. Usually, a company is owned by several shareholders and the additional funds are considered if the supervisory function of the old owner will not be reduced. Therefore, the old owner tend to consider to issue more bonds than by adding shares,

3) Earning per share, choose the sources of funds, whether from stocks or debt. In financial should have to generate profits for shareholders or higher earnings per share.

4) Level of risk or riskiness, Debt is a source risk. and the risks are high due to the interest should have to pay at the time the company has a profit or the company has a loss condition. Therefore, the higher use of debt funds indicates the company has a high degree of risk.

\subsection{Interest rate (SBI)}

An interest rate is the annual interest of loan payment in the form of the loan percentage obtained from the amount of interest earned annually divided by the loan amount (Case and Fair, 2007)

\subsection{Asset Structure (RTA)}

Fixed Assets project asset structure (Tangible Assets). Companies with large amounts of fixed assets tend to benefit from large amounts of debt. Large-scale companies more accessible funds sources than small companies (Sartono, 2001).

\subsection{Firm Size (Size)}

Public companies listed on IDX categorized into three major groups: large firm, medium and small firm (Suwito, 2012). The company size is based on the total assets of the company. Company size is a scale classified companies according to various methods including total assets, log size, stock market value, and others (Suwito, 2012).

\subsection{Profitability (ROA)}

According to (Munawir, 2007) pofitability or profitability is the ability of the company to generate profits during a particular period. The other scholars defined profitability is the ability of companies to earn profits with sales, total assets, and capital (Sartono, 2001). Profitability is the result of some company policies and decisions. Profitability ratios show the combined effects of liquidity, asset management, and debt on operating results (Brigham and Houston, 2010). Based on the prior studies, the authors developed the hypotheses in this study as follows:

H1: Interest rates, asset structure, firm size, and profitability affect the capital structure simultaneously and partially

H2: Profitability can moderate the relationship of factors affecting the capital structure

Based on this hypothesis, the authors developed a conceptual framework for this study as shown in Figure 1. 


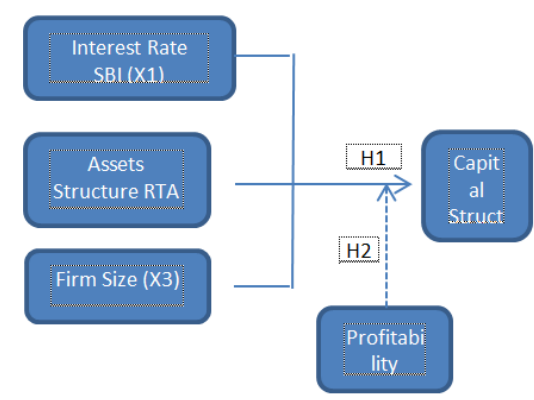

Fig. 1. Conceptual Framework.

\section{Research Method}

This study includes causal associative research which aims to analyze the relationship between one variable with another variable, or how a variable affects other variables (Umar, 2000). In this study, Independent variable (X) is the interest rate, asset structure, firm size, will be tested and analyzed how they influence to capital structure $(\mathrm{Y})$ as a dependent variable, and profitability as moderating variable $(Z)$.

\subsection{Definition of Operational Variables}

This study uses five variables. Here's the definition of operational variables

Table 1. Operationalization Variables.

\begin{tabular}{ll}
\hline Variable & Operationalization Variables \\
\hline Interest & A measure of the price of a \\
rate (X1) & $\begin{array}{l}\text { resource used by the debtor to be } \\
\text { paid to the creditor. The interest } \\
\text { rate set by Central Bank (Bank } \\
\text { Indonesia) }\end{array}$ \\
\hline Asset & The composition of the assets \\
Structure & used for the company's \\
(X2) & $\begin{array}{l}\text { operational activities. The asset } \\
\text { structure uses the fixed asset ratio }\end{array}$ \\
& $\begin{array}{l}\text { of Fixed Assets to Total Assets } \\
\text { during 2010 to 2014. }\end{array}$ \\
\hline Firm Size & $\begin{array}{l}\text { A scale can be classified large or } \\
\text { small companies by various }\end{array}$ \\
& $\begin{array}{l}\text { means, including total assets, log } \\
\text { size, stock market value, and } \\
\text { others. }\end{array}$ \\
\hline Profitabilit & The level of net profit a company \\
y (Z) & $\begin{array}{l}\text { can generate in its operations. } \\
\text { Profitability is measured by using }\end{array}$ \\
\hline Capital & Coturn on assets ratio (ROA) \\
structure & capital and external capital. \\
(Y) & \\
\hline
\end{tabular}




\subsection{Population and Sample}

The population in this study is firms of miscellaneous industry sector listed on the Indonesia Stock Exchange (IDX) for the 2010-2014 period. The sample size determines using the purposive sampling method, and obtained samples are 23 companies from 38 companies of miscellaneous industry sector listed on the Indonesia Stock Exchange (IDX).

\subsection{Types and Data Collection Methods}

This study used quantitative data type which aims to conclude. Data collection using documentation methods from various kinds of literature related to this study.

\subsection{Data Analysis Method}

Data analysis in this study used panel data regression with intercept assumption, and slope coefficients constant over time. This assumption is the simplest by ignoring the dimension of time and space. Directly, regression used Ordinary Least Square. Data Processing and analysis using SPSS Software (Statistical Package Social Science) version.17.

The equation of this model is:

$\mathrm{Y}=\alpha+\beta_{1} \mathrm{X}_{1}+\beta_{2} \mathrm{X}_{2}+\beta_{3} \mathrm{X}_{3}+\mathrm{e}$

Y: Capital Structure

$\begin{array}{ll}\alpha & : \text { Coefficient of Constants } \\ \beta_{1}-\beta_{3} & : \text { Regression Coefficient } \\ \mathrm{X}_{1} & : \text { Interest Rate } \\ \mathrm{X}_{2} & : \text { Asset Structure } \\ \mathrm{X}_{3} & : \text { Firm Size } \\ \mathrm{e} & : \text { Error term }\end{array}$

$\mathrm{Z}=\mathrm{a}+\mathrm{b}_{1} \mathrm{X}+\mathrm{e}$

$|\mathrm{e}|=\mathrm{a}+\mathrm{b}_{1} \mathrm{Y}$

Information:

$\mathrm{Z}=$ variables hypothesized as moderating variables.

$\mathrm{X}=$ independent variable (Interest Rate, Asset Structure, Firm Size)

$|\mathrm{e}|=$ absolute residual value

$\mathrm{Y}=$ Capital Structure

\section{Results And Discussion}

\subsection{Hypothesis Test Results Simultaneous Significance Test}

The results of statistical the F-test or simultaneous test of SBI, RTA, SIZE, ROA, DER, on DER, showed in the following table.

Table 2. Simultaneous Significance Test Results.

\begin{tabular}{|l|l|l|l|l|l|l|}
\hline \multicolumn{7}{|l|}{ Anova $^{\mathrm{a}}$} \\
\hline \multicolumn{2}{|l|}{ Model } & Sum of Squeres & df & Mean Squere & F &. .Sig \\
\hline \multirow{2}{*}{1} & Regression & 26.657 & 4 & 6.664 & 6.673 & $.000^{\mathrm{a}}$ \\
\cline { 2 - 8 } & Residual & 107.860 & 108 & .999 & & \\
\hline
\end{tabular}




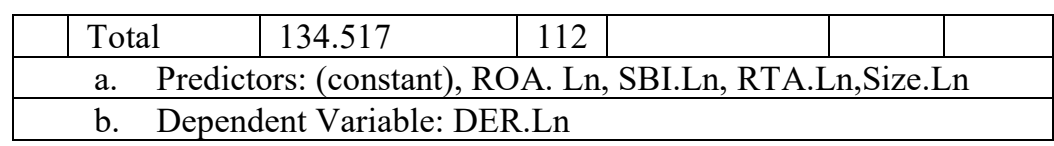

Based on the test results showed F-count value of 6.673 is higher than t-table (2.46) with significance 0,000 (Sig. $<0.05$ ). This test proves that the hypothesis (H1) the effect of SBI, RTA, SIZE, and ROA simultaneously on capital structure is proven and accepted. The result showed that SBI, RTA, SIZE, and ROA on DER simultaneously.

\subsection{Partial Significance Test}

Based on the test show the following results:

1. The result of hypothesis testing showed the effect of SBI on the capital structure obtained by t-count value of 0.97 is smaller than t-table of 1.98217 with a significance of 0.844 (Sig.> 0.05). The results of this test showed the hypothesis is unproven and rejected.

2. The results test show the value of t-count of 2.985 is higher than $t$-table of 1.98217 with a significance of 0.004 (Sig. $<0.05$ ). The result of hypothesis testing showed that RTA has a significant effect on DER is proven and accepted.

3. The result of hypothesis testing showed the effect of SIZE to DER obtained by t-count value of 0.735 is higher than t-table of 1.98217 with a significance of 0.464 (Sig.> 0.05 ). The result indicates that SIZE has not a significant effect on DER, it means the hypothesis is rejected

4. The result of hypothesis testing showed the effect of ROA to DER obtained by t-count value $(-4.297)$ is smaller than -t-table $(-1.98217)$ with significance 0.000 (Sig. $<0.05)$. The result of hypothesis testing showed that ROA has a significant effect on the capital structure is proven and accepted.

Table 3. Partial Significance Test Results.

\begin{tabular}{lllllll}
\hline Coefficients $^{\mathbf{a}}$ & \multicolumn{7}{l}{} \\
\hline \multirow{2}{*}{ Model } & \multicolumn{2}{l}{ Unstandardized coefficients } & Standardized coefficients & & \\
\cline { 3 - 7 } & & $\mathrm{B}$ & Std. Error & Beta & $\mathrm{t}$ & Sig. \\
\hline \multirow{2}{*}{1} & (constant) & -2.545 & 3.004 & & -.847 & .399 \\
\cline { 2 - 7 } & SBI.Ln & .222 & 1.122 & .017 & .197 & .844 \\
\cline { 2 - 7 } & RTA.Ln & .448 & .150 & .259 & 2.985 & .004 \\
\hline & SIZE.Ln & .585 & .796 & .066 & .735 & .464 \\
\hline & ROA.Ln & -.402 & .093 & -.385 & -4.297 & .000 \\
\hline
\end{tabular}

a. Dependent variable: DER.Ln

\subsection{Multiple Linear Regression}

Results of data processing with regression analysis are as follows:

DER $=-2.545+0,222$ SBI.Ln +

0,448RTA.Ln+0,585SIZE.Ln -

0,402ROA.Ln $+\mathrm{e}$

Based on the multiple regression equations concluded as follows: 
a) A constant value of -2.454 , and it means if the variable of capital structure is uninfluenced by the variables of SBI, RTA, SIZE, and ROA, then the DER of the listed company in IDX is equal to -2.454 units.

b) Beta coefficient value of SBI variable is 0.222 , and it means that increasing SBI of $1 \%$, then DER will rise by 0.222 units, with an assumption the other variables are considered constant.

c) Beta coefficient value of RTA variable is 0.448 , and it means that increasing RTA of $1 \%$, then DER will rise by 0.448 units, with an assumption the other variables are considered constant.

d) Beta coefficient value of SIZE variable is 0.585 , and it means that increasing SIZE of $1 \%$, then the DER will rise by 0.585 units, with an assumption the other variables are considered constant.

e) Beta coefficient value for ROA variable is -0.402 means that each ROA increase of $1 \%$, then DER will drop by 0.402 units, with an assumption the other variables are considered constant.

\subsection{Results of Second Hypothesis Data Analysis}

The following hypothesis test used the multiple regressions with a residual test. The second hypothesis testing was conducted to test the moderating variable used profitability (ROA), whether to strengthen or weaken the relationship between the independent variables of SBI, RTA, SIZE and the dependent variable (DER). The result of an equation of residual test showed in the following table.

Table 4. Moderating Test Result.

\begin{tabular}{|c|c|c|c|c|c|c|}
\hline \multicolumn{7}{|c|}{ Coefficients } \\
\hline \multirow{2}{*}{\multicolumn{2}{|c|}{ Model }} & Unsta & dized coefficients & Stand & & \\
\hline & & $\mathrm{B}$ & Std. Error & Beta & $\mathrm{t}$ & Sig. \\
\hline \multirow[t]{2}{*}{1} & (constant) & .600 & .135 & & 4.448 & .000 \\
\hline & DER.Ln & -.071 & .058 & -.114 & -1.214 & .227 \\
\hline
\end{tabular}

a. Dependent variable: AbsRes 1

Based on the result of moderating test, the residual test model can be formulated in the form of equation as follows:

$$
|\mathrm{e}|=0,600-0,071 \mathrm{DER}+\mathrm{e}
$$

Based on the result of the residual test, the value of $t$-count $(-1.214)$ is greater than $-t$ table (-1.98217) with a significance of $0.227>0.05$, with negative coefficient direction, it concluded the variable of capital structure has a negative effect on absolute residual. The results test proved that variable of profitability cannot strengthen or weaken the relationship between SBI, RTA, SIZE on DER in firms of miscellaneous industry sector listed on the Indonesia Stock Exchange (IDX). Therefore, the conclusion is variable of profitability cannot be moderating variable in this study. 


\section{Conclusion}

The variables of SBI, RTA, SIZE, and ROA have the significant effect on the capital structure simultaneously in firms of miscellaneous industry sector listed on the Indonesia Stock Exchange (IDX) for the 2010-2014 periods. In separate, the results of partial tests only RTA and ROA variables have the significant effect on the capital structure in firms of miscellaneous industry sector listed on the Indonesia Stock Exchange (IDX) for the 20102014 periods. Variable SBI and SIZE variables have no significant effect on capital structure in the company Sector Assorted Industries registered in IDX for 2010- 2014.Value of profitability unable to moderate the relationship of SBI, RTA, and SIZE with capital structure in firms of miscellaneous industry sector listed on the Indonesia Stock Exchange (IDX) for the 2010-2014 period.

\section{Future Scope}

Further study is expected to develop this study by increasing the number of other independent variables such as sales, risk, corporate growth, liquidity, free cash flow. Additional variables are expected find the other effect of capital structure. The authors expect for the future researchers to add samples beside the companies from the miscellaneous industries sector, such as the financial sector, mining sector, telecommunications sector, trade sector and other sectors to compare the results among the sectors in IDX.

\section{Acknowledgements}

The authors gratefully acknowledge the financial support from Universitas Pembangunan Panca Budi, and we would like to thank the reviewers for guidance sincerely.

\section{References}

[1] Bambang, R. (2001) Dasar-dasar pembelanjaan perusahaan. Edisi Keem. Yogyakarta: BPFE Yogyakarta.

[2] Brigham and Houston (2010) Essentials of financial management. Engage Learning Asia.

[3] Case and Fair (2007) Principles of microeconomics. Pearson Education.

[4] Munawir (2007) Analisa Laporan Keuangan. Yogjakarta: Liberty.

[5] Myers, S. C. (1984) 'The capital structure puzzle.', The journal of finance, 39(3), pp. 574-592.

[6] Sartono, A. (2001) Manajemen keuangan teori dan aplikasi. Yogyakarta: BPFE.

[7] Suwito, H. and (2012) 'Analisis pengaruh karakteristik perusahaan terhadap tindakan perataan laba yang dilakukan oleh perusahaan yang terdaftar di Bursa Efek Jakarta.'

[8] Umar, H. (2000) Metodologi Penelitian. Jakarta: Gramedia Pustaka Umum.

[9] Wijaya, K. and (2005) Riset Keuangan: Pengujian-Pengujian Empiris. Jakarta: PT Gramedia Pustaka Utama.

[10] www.idx.co.id. 2015. Indonesia Stock Exchange (IDX): Fact Book 2007 - 2011

[11] www.bi.go.id. 2015. Bank Indonesia 